\title{
PENGARUH UMUR PERUSAHAAN, LIKUIDITAS DAN \\ PROFITABILITAS TERHADAP KETEPATAN WAKTU \\ PENYAMPAIAN LAPORAN KEUANGAN “(TIMELINESS)”
}

\author{
Retna Sari \\ retnafull@yahoo.com \\ Fakultas Ekonomi UPN "Veteran" Jakarta \\ Jl. R.S. Fatmawati Pondok Labu, Jakarta Selatan - 12450
}

ABSTRACT

This research was conducted to examine the effect age of company, likuidity and profitability to timeliness in the submission of the financial report of manufacturing in Indonesia Stock Exchange period 2012. Sample that as many as 92 companies. Sample determination technique using purposive sampling method. Hypotesis testing using a logistic anlysis. The result showed that all variables are not significantly to the timeliness. Keywords : age of company, liquidity,profitability, timeliness

\section{PENDAHULUAN}

\section{Latar Belakang Penelitian}

Ketepatan waktu (timeliness) merupakan salah satu faktor penting dalam menyajikan suatu informasi yang relevan terutama bagi laporan keuangan. Karena ketepatan waktu merupakan salah satu karakteristik kualitatif yang harus dipenuhi agar laporan keuangan yang disajikan relevan untuk membantu dalam pembuatan keputusan. Informasi dari laporan keuangan yang disajikan tepat waktu dan akurat akan sangat bermanfaat bagi pengguna laporan keuangan. Dyer McHugh (1975) menyatakan bahwa ketepatan waktu pelaporan keuangan merupakan elemen pokok bagi catatan laporan keuangan. Disamping hal tersebut, Owusu dan Ansah (2000) menyatakan bahwa ketepatan waktu pelaporan keuangan akan memberikan andil bagi kinerja yang efisien di pasar saham yaitu sebagai fungsi evaluasi dan pricing, membantu mengurangi tingkat insider trading dan kebocoran serta rumor di pasar saham.

Beberapa peneliti yang ketepatan waktu penyampaian laporan keuangan dan menunjukkan hasil yang belum konsisten. Diantaranya hasil penelitian Owusu \& Ansah (2000) dan Iyoha F.O (2012) menyatakan bahwa umur perusahaan berpengaruh signifikan terhadap ketepatan waktu penyampaian laporan keuangan (timeliness). Namun penelitian ini bertentangan dengan hasil penelitian Saleh (2004) dan Yusralaini, dkk (2010) yang menyatakan bahwa umur perusahaan tidak berpengaruh signifikan terhadap ketepatan waktu penyampaian laporan keuangan (timeliness).

Terkait dengan likuiditas terhadap ketepatan waktu penyampaian laporan keuangan yang belum konsisten ditetapkan oleh hasil penelitian Hilmi dan Ali (2006) dan Suharli dan Rachpriliani (2006) yang menyatakan bahwa likuiditas 
berpengaruh signifikan terhadap ketepatan waktu penyampaian laporan keuangan (timeliness). Namun hal ini bertentangan dengan hasil penelitian Yusralaini, dkk (2010) menyatakan bahwa likuiditas berpengaruh tidak signifikan terhadap ketepatan waktu penyampaian laporan keuangan (timeliness).

Penelitian

pengaruh profitabilitas terhadap ketepatan waktu penyampaian laporan keuangan yang belum konsisten ditentukan oleh hasil penelitian Na'im (1999) dan Saleh (2004) menyatakan bahwa profitabillitas berpengaruh signifikan terhadap ketepatan waktu penyampaian laporan keuangan (timeliness). Namun hal ini bertentangan dengan hasil penelitian Agrianti (2003) dan Aryati dan Theresia (2005) yang menyatakan bahwa profitabilitas berpengaruh tidak signifikan terhadap ketepatan waktu penyampaian laporan keuangan (timeliness).

\section{Perumusan Masalah}

Berdasarkan latar belakang masalah yang telah dikemukakan diatas, maka rumusan masalah penelitian sebagai berikut :

a. Apakah Umur Perusahaan berpengaruh signifikan terhadap Kemungkinan Ketepatan Waktu Penyampaian Laporan Keuangan (timeliness)?

b. Apakah Likuiditas berpengaruh signifikan terhadap Kemungkinan Ketepatan Waktu Penyampaian Laporan Keuangan (timeliness)?

c. Apakah Profitabilitas berpengaruh signifikan terhadap Kemungkinan
Ketepatan Waktu Penyampaian Laporan Keuangan (timeliness)?

\section{TINJAUAN PUSTAKA DAN PENGEMBANGAN HIPOTESIS Teori Kepatuhan (Compliance Theory)}

Teori kepatuhan telah diteliti dalam ilmu-ilmu sosial khususnya di bidang psikologi dan sosiologi yang lebih menekankan pada pentingnya proses sosialisasi dalam mempengaruhi perilaku kepatuhan seorang individu. Menurut Tyler (dalam Saleh 2004) terdapat dua perspektif dasar mengenai kepatuhan hukum yaitu instrumental dan normatif. Perspektif instrumental mengasumsikan individu secara utuh didorong oleh kepentingan pribadi dan tanggapan-tanggapan terhadap perubahan insentif, dan penalti yang berhubungan dengan perilaku. Perspektif normatif berhubungan dengan apa yangg orang anggap sebagai moral dan berlawanan dengan kepentingan pribadi mereka.

Seorang individu cenderung mematuhi hukum yang mereka anggap sesuai dan konsisten dengan normanorma internal mereka. Komitmen normatif melalui moralitas personal (normative commitment through morality) berarti mematuhi hukum karena hukum tersebut dianggap sebagai keharusan, sedangkan komitmen normatif melalui legitimasi (normative commitment through legitimacy) berarti mematuhi peraturan karena otoritas penyusun hukum tersebut memiliki hak untuk mendikte perilaku.

Adanya teori kepatuhan dapat mendorong seseorang untuk mematuhi 
setiap peraturan yang berlaku, maka perusahaan secara tidak langsung akan mematuhi peraturan yang dikeluarkan oleh Bapepam dan perusahaan akan selalu berusaha untuk menyampaikan laporan keuangannya secara tepat waktu.

\section{Ketepatan Waktu Penyampaian Laporan Keuangan (Timeliness)}

Tepat waktu adalah karakteristik kualitatif dari informasi akuntansi yang sampai di tangan pengguna tepat pada waktunya untuk membantu dalam pengambilan keputusan Ardiyos (2010:928). Dan menurut Suwardjono (2010:170) menyatakan bahwa ketepatwaktuan adalah tersedianya informasi bagi pembuat keputusan pada saat dibutuhkan sebelum informasi tersebut kehilangan kekuatan untuk mempengaruhi keputusan.

Dyer dan McHugh (1975) menggunakan tiga kriteria keterlambatan untuk melihat ketepatan waktu dalam penelitiannya:

1) Preliminary lag, yaitu internal jumlah hari antara tanggal laporan keuangan sampai penerimaan laporan akhir preleminary oleh bursa,

2) Auditor's report lag: interval jumlah hari antara tanggal laporan keuangan sampai tanggal laporan auditor ditandatangani,

3) Total lag: interval jumlah hari antara tanggal laporan keuangan sampai tanggal penerimaan laporan dipublikasikan oleh bursa.

Menurut Owushu dan Ansah (2000) menyatakan secara konseptual bahwa tepat waktu adalah kualitas ketersediaan informasi pada saat yang diperlukan atau kualitas informasi yang baik dilihat dari segi waktu.

\section{Umur Perusahaan}

Menurut Heizer dan Render (2005:694) menyatakan bahwa "kurva belajar merupakan dasar pemikiran yang menyatakan bahwa organisasi dan orang-orang mengerjakan tugas mereka lebih baik ketika tugas diulangi". Mnurut Owushu dan Ansah (2000) menyatakan bahwa ketika sebuah perusahaan berkembang dan para akuntannya belajar lebih banyak masalah pertumbuhan, menyebabkan penundaan yang luar biasa dapat diminimalisasikan. Akibatnya perusahaan mapan yang memiliki umur lebih tua cenderung menjadi lebih mahir dalam pengumpulan, pengolahan dan menghasilkan informasi ketika diperlukan karena pengalaman belajar.

Ketika perusahaan memiliki umur yang panjang maka perusahaan tersebut mempunyai para akuntan yang sudah berpengalaman dan terampil dalam menyusun laporan keuangan sehingga semakin sering para akuntan belajar dan mengulangi maka perusahaan akan tepat waktu dalam menyampaikan laporan keuangannya.

Namun Yusralaini, dkk (2010) menyatakan bahwa umur perusahaan tidak berpengaruh terhadap ketepatan waktu penyampaian laporan keuangan. Sebab, perusahaan yang terdaftar lebih dulu di BEI cenderung melaporkan Laporan Keuangan dengan tepat waktu. 
Likuiditas

Menurut Subramanyam dan Jhon (2010: 43) Likuiditas perusahaan, menunjukkan kemampuan perusahaan untuk memenuhi kewajiban jangka pendeknya. Menurut Brigham dan Houston (2010: 134) menyatakan bahwa rasio likuiditas yaitu rasio yang menunjukkan hubungan antara kas dan aset lancar perusahaan lainnya dengan kewajiban lancarnya. Menurut Weston dalam Kasmir (2011: 129) Rasio likuiditas (liquidity ratio) merupakan rasio yang menggambarkan kemampuan perusahaan dalam memenuhi kewajiban (utang) jangka pendek.

\section{Profitabilitas}

Profitabilitas adalah kemampuan perusahaan dalam menghasilkan laba dengan menggunakan sumber daya yang dimiliki oleh perusahaan untuk periode tertentu. Profitabilitas merupakan salah satu indikator keberhasilan perusahaan untuk dapat menghasilkan laba sehingga semakin tinggi profitabilitas maka semakin tinggi kemampuan perusahaan untuk menghasilkan laba bagi perusahaannya Hilmi dan Ali (2008).

\section{Pengembangan Hipotesis}

Pengembangan hipotesis merupakan jawaban sementara atas masalah penelitian. Pada bagian ini dijelaskan pengembangan hipotesis berdasarkan teori yang digunakan dan acuan hasil penelitian terdahulu.

\section{Pengaruh Umur Perusahaan terhadap Ketepatan Waktu Penyampaian Laporan Keuangan (Timeliness)}

Umur perusahaan adalah lamanya perusahaan terdaftar sebagai perusahaan publik di BEI. Umur perusahaan dikaitkan dengan sebuah teori yang dinamakan dengan learning curve (kurva belajar). Ketika perusahaan memiliki umur yang panjang maka perusahaan tersebut mempunyai para akuntan yang sudah berpengalaman dan terampil dalam menyusun laporan keuangan sehingga semakin sering para akuntan belajar dan mengulangi maka perusahaan akan tepat waktu dalam menyampaikan laporan keuangannya. Penelitian yang dilakukan Owusu dan Ansah (2000) dan Iyoha (2012) yang menyatakan bahwa umur perusahaan berpengaruh signifikan negatif terhadap ketepatan waktu penyampaian laporan keuangan. Artinya semakin tua umur perusahaan maka akan lebih terampil dan tepat waktu dalam menyampaikan laporan keuangannya.

Berdasarkan landasan teori dan hasil penelitian terdahulu mengenai umur perusahaan dan pengaruhnya terhadap ketepatan waktu penyampaian laporan keuangan (timeliness) yang telah dikemukakan tersebut, maka hipotesis yang dapat dikembangkan adalah :

$\mathrm{H}_{1}$ : Umur perusahaan berpengaruh signifikan terhadap kemungkinan ketepatan waktu penyampaian laporan keuangan (timeliness).

Pengaruh Likuiditas terhadap Ketepatan Waktu Penyampaian Laporan Keuangan (Timeliness)

Likuiditas adalah kemampuan perusahaan dalam membayar hutang 
jangka pendeknya. Jika likuiditas tinggi maka terlihat bahwa perusahaan mampu membayar hutangnya dengan tepat waktu. Disisi lain perusahaan yang membayar dengan tepat waktu akan terlihat memiliki komitmen yang tinggi. Hal tersebut akan dilihat baik oleh para investor. Oleh karena itu perusahaan harus menyampaikan laporan keuangan dengan tepat waktu agar berita baik dapat diterima oleh para pengguna laporan keuangan. Penelitian Suharli dan Rachpriliani (2006) dan Hilmi dan ali (2008) menunjukkan bahwa likuiditas berpengaruh signifikan positif terhadap ketepatan waktu penyampaian laporan keuangan. Artinya jika likuiditas tinggi maka perusahaan cenderung akan menyampaikan laporan keuangan tepat waktu.

Berdasarkan landasan teori dan hasil penelitian terdahulu mengenai likuiditas dan pengaruhnya terhadap ketepatan waktu penyampaian laporan keuangan (timeliness) yang telah dikemukakan tersebut, maka hipotesis yang dapat dikembangkan adalah:

$\begin{array}{rlr}\mathrm{H}_{2}: & \text { Likuiditas perusahaan } \\ & \text { berpengaruh signifikan } \\ & \text { terhadap ketepatan waktu } \\ & \text { penyampaian lporan keuangan } \\ & \text { (timeliness). }\end{array}$

Pengaruh Profitabilitas terhadap Ketepatan Waktu Penyampaian Laporan Keuangan (Timeliness)

Profitabilitas adalah kemampuan perusahaan dalam menghasilkan laba dengan menggunakan sumber daya yang dimiliki oleh perusahaan untuk periode tertentu. Laba bagi perusahaan merupakan suatu berita baik untuk perusahaan. Bagi investor berita baik tersebut akan mempengaruhi keputusannya untuk berinvestasi. Sehingga perusahaan harus menyampaikan laporan keuangan tepat waktu agar berita tersebut lebih cepat diketahui oleh investor. Hasil penelitian Hilmi dan Ali (2008) menunjukkan bahwa profitabilitas berpengaruh signifikan positif terhadap ketepatan waktu penyampaian laporan keuangan. Artinya semakin tinggi tingkat profitabilitas maka perusahaan cenderung tepat waktu dalam menyampaiakan laporan keuangannya. Berdasarkan landasan teori dan hasil penelitian terdahulu mengenai profitabilitas dan pengaruhnya terhadap ketepatan waktu penyampaian laporan keuangan (timeliness) yang telah dikemukakan tersebut, maka hipotesis yang dapat dikembangkan adalah :

$\begin{array}{rrr}\mathrm{H}_{3}: & \text { Profitabilitas } & \text { berpengaruh } \\ & \text { signifikan } & \text { terhadap } \\ & \text { kemungkinan } & \text { ketepatan waktu } \\ & \text { penyampaian } & \text { laporan } \\ & \text { keuangan (timeliness). }\end{array}$

\section{Pengukuran dan Definisi Operasional Variabel}

Definisi operasional variabel dalam penelitian ini adalah sebagai berikut:

1. Umur Perusahaan $\left(\mathbf{X}_{1}\right)$, adalah lamanya perusahaan terdaftar sebagai perusahaan publik di BEI. Variabel ini diukur sejak tanggal listing perusahaan di BEI (Owushu dan Ansah, 2000). Data diperoleh dari laporan keuangan perusahaan. Skala data yang digunakan adalah skala data rasio. 
2. Likuiditas $\left(\mathbf{X}_{2}\right), \quad$ adalah ketersediaan sumber daya (kemampuan) perusahaan untuk memenuhi kewajiban jangka pendeknya yang jatuh tempo secara tepat waktu (Hilmi dan Ali, 2008). Variabel ini diukur dengan model yang digunakan oleh Brigham dan Houston (2010:134) yaitu dengan membagi asset lancar dengan kewajiban lancar, seperti berikut ini:

$$
\text { Rasio lancar }=\frac{\text { Asset Lancar }}{\text { Kewajiban Lancar }}
$$

Data diperoleh dari laporan keuangan perusahaan pada bagian neraca. Skala data yang digunakan adalah skala data rasio.

3. Profitabilitas $\left(\mathbf{X}_{\mathbf{3}}\right)$ adalah indikator keberhasilan perusahaan dalam menghasilkan laba (Hilmi dan Ali, 2008). Variabel ini diukur dengan Return On Asset (ROA) yang digunakan oleh Brigham dan Houston (2010:148) yaitu dengan pengembalian atas total aset, seperti berikut ini:

$R O A=\frac{\text { Laba bersih }}{\text { Total aset }}$

Data diperoleh dari laporan keuangan perusahaan. Skala data

\section{Kerangka Penelitian}

Berdasarkan dari penjelasanpenjelasan yang telah dikemukakan sebelumnya maka dapat digambarkan dengan kerangka penelitian sbb. : yang digunakan adalah skala data rasio.

4. Ketepatan waktu penyampaian laporan keuangan (timeliness $(\mathrm{Y})$ adalah rentang waktu atau lamanya hari yang dibutuhkan untuk mengumumkan laporan keuangan tahunan yg telah diaudit kepada publik (Aryati dan Theresia, 2005). diukur berdasarkan tanggal penyampaian laporan keuangan tahunan auditan ke Badan Pengawas Pasar Modal dan Lembaga Keuangan (BapepamLK). Skala data diukur dengan menggunakan variabel dummy dengan kategori untuk perusahaan yang tidak tepat waktu masuk kategori 0 (menyampaiakan laporan keuangannya lebih dari 90 hari setelah tanggal laporan keuangan) dan untuk perusahaan yang memiliki ketepatan waktu masuk kategori 1 (menyampaikan laporan keuangannya kurang dari 90 hari setelah tanggal laporan keuangan). Data ini diperoleh dari tanggal penyampaian laporan keuangan tahunan auditan perusahaan ke Bapepam-LK. 


\section{Gambar}

\section{Diagram Kerangka Penelitian}

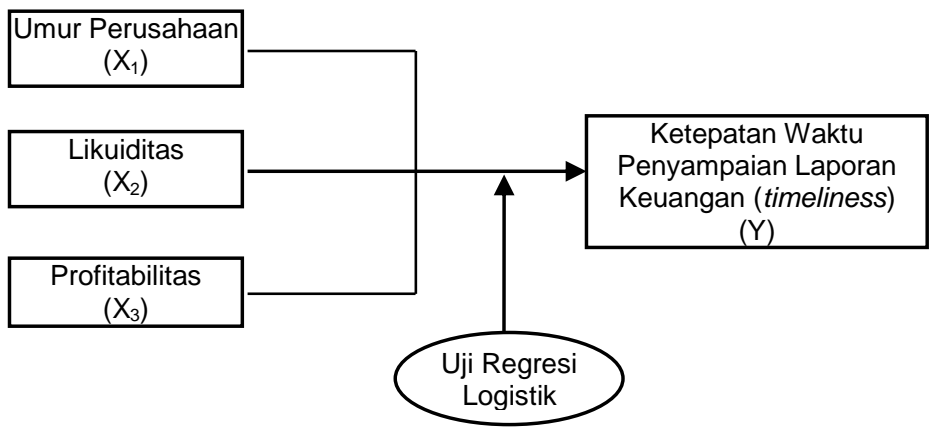

METODE PENELITIAN

Populasi dan Pengambilan Sampel

Populasi yang digunakan dalam penelitian ini adalah perusahaan manufaktur yang telah go public dan menerbitkan laporan keuangan yang diaudit dan dipublikasikan di Bursa Efek Indonesia (BEI) untuk periode tahun 2012. Sampel adalah bagian dari jumlah dan karakteristik yang dimiliki oleh populasi tersebut. Dari perusahaan manufaktur yang telah go public untuk periode tahun 2012. Metode pengambilan sampel yang digunakan adalah purposive sampling, dimana populasi yang akan dijadikan sampel penelitian adalah populasi yang memenuhi kriteria sampel tertentu.

Kriteria-kriteria tersebut adalah sebagai berikut:

1. Perusahaan manufaktur yang terdaftar di BEI untuk periode tahun 2012.

2. Perusahaan tersebut telah menerbitkan laporan keuangan untuk periode tahun 2012.

3. Perusahaan yang memiliki data tanggal penyampaian laporan keuangan ke Bapepam untuk periode tahun 2012.

4. Menampilkan data dan informasi yang digunakan untuk menganalisis faktor-faktor yang mempengaruhi ketepatan waktu penyampaian laporan keuangan untuk periode tahun 2012.

5. Perusahaan yang menerbitkan laporan keuangan dalam rupiah (Rp).

\section{Metode Analisis Data dan Uji Hipotesis}

Teknis analisis data yang digunakan Statistik Deskriptif yang memberikan gambaran atau deskripsi suatu data yang dilihat dari nilai minimum, nilai maksimum, nilai ratarata (mean), dan standar deviasi (Ghozali, 2011:19). Untuk uji hipotesis menggunakan Analisis Regresi Logistik, karena variabel dependennya merupakan data nominal dan variabel independennya data rasio.

Model regresi logistik yang digunakan dalam penelitian ini dapat dinyatakan dalam persamaan sebagai berikut : 


$$
\begin{aligned}
\operatorname{Ln} \frac{\text { TIME }}{1-\text { TIME }} & =\alpha+\beta 1 \mathrm{AGE} \\
& +\beta 2 \mathrm{CR}+\beta 3 \mathrm{ROA} \\
& +\varepsilon
\end{aligned}
$$

Keterangan :

$$
\begin{aligned}
& \text { Ln } \frac{\text { TIME }}{1-\text { TIME }} \text { : Ketepatan Waktu } \\
& \text { Penyampaian Laporan } \\
& \text { Keuangan } \\
& \alpha \quad \text { : Konstanta } \\
& \beta_{1} \beta_{2} \quad \text { : Koefisien regresi untuk } \\
& \text { tiap variabel } \\
& \text { AGE : Umur Perusahaan (First } \\
& \text { Issue) } \\
& \text { CR : Likuiditas (Current } \\
& \text { Ratio) } \\
& \text { PROF : Profitabilitas yang } \\
& \text { diukur dengan Return } \\
& \text { On Asset (ROA) } \\
& \varepsilon \quad: \begin{array}{ll}
\text { Error } \\
\text { Gangguan) }
\end{array}
\end{aligned}
$$

Pengujian terhadap model regresi logistik pada penelitian ini tidak digunakan uji normalitas karena variabel bebas merupakan campura antara variabel metrik dan non metrik atau data yang digunakan tidak normal. Sehingga pengujian model regresi logistik akan dilakukan dalam beberapa tahap, yaitu uji multikolonieritas, Hosmer and Lameshow's Goodness of Fit Test,

\begin{tabular}{|c|c|c|}
\hline No & Kriteria Sampel Penelitian & Total \\
\hline 1. & $\begin{array}{l}\text { Jumlah semua perusahaan } \\
\text { manufaktur untuk tahun } 2012\end{array}$ & 128 \\
\hline 2. & $\begin{array}{l}\text { Jumlah perusahaan yang tidak } \\
\text { menerbitkan laporan keuangan }\end{array}$ & (7) \\
\hline 3. & $\begin{array}{l}\text { Jumlah yang menerbitkan laporan } \\
\text { keuangan dengan satuan dolar }(\$)\end{array}$ & (22) \\
\hline 4 & $\begin{array}{l}\text { Jumlah perusahaan yang tidak } \\
\text { menyampaikan laporan keuangan } \\
\text { ke Bapepam }\end{array}$ & (7) \\
\hline & $\begin{array}{l}\text { Jumlah total sampel selama } \\
\text { periode penelitian }\end{array}$ & 92 \\
\hline
\end{tabular}
Menilai Keseluruhan Model (Overall Model Fit Test), Menguji koefisien determinasi (Model Summary), pengujian simultan dan menguji koefisien regresi (uji parsial)

\section{HASIL DAN PEMBAHASAN Deskripsi Objek Penelitian}

Objek penelitian yang digunakan adalah perusahaan manufaktur yang sudah go public yaitu yang terdaftar di Bursa Efek Indonesia selama periode 2012 (1 tahun). Sampel diseleksi berdasarkan kriteria yang telah ditetapkan sebagai berikut :

Tabel Pembagian Sampel

\section{Deskripsi Data Penelitian}

Data penelitian yang akan digunakan sebanyak 92 sampel perusahaan. Data dengan tingkat signifikansi $(\alpha)$ sebesar $5 \%$ atau 0,05 . Pengujian statistik deskriptif digunakan untuk memberikan informasi gambaran umum dari tiap variabel penelitian. Berikut ini adalah distribusi frekuensi ketepatan waktu penyampaian laporan keuangan (timeliness). 


\section{Tabel Frequency Ketepatan Waktu Penyampaian Laporan Keuangan (timeliness)}

Ketepatan Waktu

\begin{tabular}{|c|c|c|c|c|c|}
\hline & & Frequency & Percent & Valid Percent & $\begin{array}{l}\text { Cumulative } \\
\text { Percent }\end{array}$ \\
\hline Valid & $\begin{array}{l}\text { Terlambat } \\
\text { Tepat Waktu } \\
\text { Total }\end{array}$ & $\begin{array}{l}17 \\
75 \\
92\end{array}$ & $\begin{array}{l}18.5 \\
81.5 \\
100.0\end{array}$ & $\begin{array}{l}18.5 \\
81.5 \\
100.0\end{array}$ & $\begin{array}{l}18.5 \\
100.0\end{array}$ \\
\hline
\end{tabular}

Sumber : Data sekunder yang telah diolah

Dari tabel diatas dapat dilihat bahwa dari 92 perusahaan, terdapat 17 perusahaan yang terlambat dalam menyampaikan laporan keuangan dengan persentase $18,5 \%$. Sedangkan sebanyak 75 perusahaan atau sebesar $81,5 \%$ yang memiliki ketepatan waktu dalam dalam menyampaikan laporan keuangan ke Bapepam. Hal ini dapat menunjukkan bahwa masih saja ada perusahaan yang tidak mematuhi peraturan yang dikeluarkan oleh Bapepam.

Berikut ini adalah statistik deskriptif dari variabel yang diteliti, yaitu umur perusahaan, likuiditas, dan profitabilitas dengan variabel dependen ketepatan waktu penyampaian laporan keuangan (timeliness).

\section{Tabel Statistik Deskriptif}

Descriptive Statistics

\begin{tabular}{|l|l|l|l|l|l|}
\hline & $\mathrm{N}$ & Minimum & Maximum & Mean & Std. Deviation \\
\hline Umur Perusahaan & 92 & .04 & 35.91 & 16.8086 & 7.69248 \\
Likuiditas & 92 & .23 & 1005.18 & 13.3504 & 104.56202 \\
Profitabilitas & 92 & -1.07 & 5.89 & .1234 & .62639 \\
Ketepatan Waktu & 92 & 0 & 1 & .82 & .390 \\
Valid N (listwise) & 92 & & & & \\
\hline
\end{tabular}

Sumber : Data sekunder yang telah diolah

Dari tabel diatas hasil statistik deskriptif dapat diketahui bahwa jumlah sampel yang digunakan dalam penelitian ini adalah 92 perusahaan. Dari tabel dapat diketahui rata-rata ketepatan waktu penyampaian laporan keuangan (TIME) pada seluruh perusahaan manufaktur untuk satu tahun yaitu tahun 2012 adalah 0,82 dengan standar deviasi sebesar 0,390. Nilai rata-rata ini mendekati nilai 1 , dimana kemungkinan ketepatan waktu penyampaian laporan keuangan besar yang dapat terlihat pada tabel diatas.
Terdapat nilai minimum sebesar 0 dan nilai maximum sebesar 1 . Hal ini dikarenakan variabel ketepatan waktu penyampaian laporan keuangan (timeliness) adalah variabel dummy yang diukur dengan kategori 0 untuk perusahaan terlambat (menyampaiakan laporan keuangannya lebih dari 90 hari setelah tanggal laporan keuangan tahunan atau setelah tanggal 31 Maret) dan kategori 1 untuk perusahaan tepat waktu dalam menyampaikan laporan keuangannya (menyampaikan laporan 
keuangannnya kurang dari 90 hari setelah tanggal laporan keuangan.

Variabel umur perusahaan yang diukur sejak tanggal listing perusahaan di BEI sampai dengan periode sampel pada tahun 2012 yang menghasilkan nilai minimum 0,04 yang berasal dari PT Wismak Inti Makmur Tbk (WIIM). Hal ini berarti umur perusahaan yang paling muda dari perusahaan manufaktur yang memenuhi kriteria adalah sebesar 0,04 tahun atau selama 14 hari. Sementara dari nilai maximum sebesar 35,91 yang berasal dari PT Holcim Indonesia Tbk (SMCB). Hal ini dapat terlihat bahwa umur perusahaan paling tua dari perusahaan manufaktur yang memenuhi kriteria selama 35 tahun. Untuk nilai rata-rata variabel umur perusahaan sebesar 16,8086 dan standar deviasi memiliki nilai sebesar 7,69248.

Variabel likuiditas pada tabel 4.4 menunjukkan nilai minimum sebesar 0,23 atau tingkat yang paling rendah berasal dari PT Alam Karya Unggul Tbk (AKKU). Nilai maximum sebesar 1005,18 atau tingkat yang paling tinggi berasal dari PT Davomas Abadi Tbk (DAVO). Hal ini berarti menunjukkan sejauh mana asset lancar menutupi kewajiban lancar atau yang dikenal dengan current ratio. Untuk nilai rata-rata variabel likuiditas adalah sebesar 13,3504 dan standar deviasi sebesar 104,56202.

Variabel profitabilitas pada tabel 4.4 menunjukan nilai nilai minimum sebesar $-1,07$ yang berasal dari PT Davomas Abadi Tbk (DAVO). Hal ini berarti untuk mengukur tingkat efisiensi dan efektivitas yang diukur dengan aset pada perusahaan ini rendah. Sementara dari nilai maximum sebesar 5,89 didapat dari PT Bentoel Jaya Manunggal Tbk (BTON) maka nilai tersebut dapat menunjukkan bahwa untuk mengukur tingkat efisiensi dan efektivitas yang diukur dengan aset pada perusahaan ini tinggi. Untuk nilai rata-rata variabel profitabilitas sebesar 0,1234 atau $12,34 \%$. Nilai rata-rata menunjukkan positif bahwa untuk mengukur tingkat efisien dan efektivitas yang diukur dengan aset, perusahaan sampel mampu menghasilkan laba selama periode penelitian. Nilai standar deviasi yang dihasilkan sebesar 0,62639. Nilai standar deviasi yang kecil menunjukkan bahwa data terdistribusi di sekitar rata-rata yang menunjukkan gambaran sebenarnya.

\section{Analisis Data dan Uji Hipotesis}

Uji hipotesis dilakukan dengan menggunakan regresi logistik (logistic regression). Digunakannya analisis regresi logistik karena variabel dependen dalam penelitian ini merupakan variabel kategorikal (nonmetrik). Teknik analisis tidak memerlukan uji normalitas pada variabel bebasnya karena variabel bebas merupakan campuran antara variabel metrik dan non metrik atau data yang digunakan tidak normal (Ghozali, 2011:333). Metode yang digunakan dalam regresi logistik yaitu metode enter dengan tingkat signifikansi $(\alpha) 5 \%$ atau 0,05

\section{Uji Multikolonieritas}

Uji multikolonieritas bertujuan untuk menguji apakah model regresi ditemukan adanya korelasi antar 
variabel bebas (independen). Model regresi yang baik seharusnya tidak terjadi korelasi antar variabel independen.

\section{Tabel Hasil Uji Multikolonieritas Coefficients $^{\mathrm{a}}$}

\begin{tabular}{|ll|l|l|}
\hline \multirow{2}{*}{ Model } & \multicolumn{2}{|l|}{ Collinearity Statistics } \\
\cline { 2 - 4 } & Tolerance & VIF \\
\hline $1 \quad$ Constant) & & \\
& Umur Perusahaan & .998 & 1.002 \\
& Likuiditas & .960 & 1.041 \\
& Profitabilitas & .959 & 1.043 \\
\hline
\end{tabular}

a. Dependent Variable: Ketepatan Waktu Sumber : Data sekunder yang telah diolah

Jika nilai tolerance $\leq 0,10$ atau sama dengan nilai VIF $\geq 10$ maka menunjukkan adanya multikolonieritas (Ghozali, 2011:106). Dari tabel diatas dapat terlihat bahwa masing-masing variabel independen yang memiliki nilai tolerance lebih dari 0,10 yaitu umur perusahaan (AGE) sebesar 0,998, likuiditas (CR) sebesar 0,960 dan profitabilitas (ROA) sebesar 0,959 dan untuk nilai VIF kurang dari 10 yaitu umur perusahaan (AGE) sebesar 1,002, likuiditas (CR) sebesar 1,041 dan profitabilitas (ROA) sebesar 1,043. Sehingga hal ini dapat disimpulkan bahwa antar variabel independen tidak ditemukan adanya korelasi atau tidak ada unsur multikolonieritas.

\section{Uji Hosmer and Lomeshow's Goodness of Fit Test}

Kelayakan model regresi dinilai dengan menggunakan Hosmer and Lemeshow's Goodness of Fit Test. Pengujian ini digunakan untuk menguji hipotesis nol bahwa data empiris cocok atau sesuai dengan model (tidak ada perbedaan antara model dengan data, sehingga model dapat dikatakan fit).

Apabila nilai statistik Hosmer and Lemeshow's Goodness of Fit Test lebih besar dari 0,05 maka hipotesis nol diterima dan mampu memprediksi nilai observasinya atau dapat dikatakan model dapat diterima karena cocok dengan data observasinya.

\section{Tabel Hasil Uji Kelayakan Model regresi}

Hosmer and Lemeshow Test

\begin{tabular}{|l|l|l|l|}
\hline Step & Chi-square & df & Sig. \\
\hline 1 & 1.236 & 8 & .996 \\
\hline
\end{tabular}

Sumber : Data sekunder yang telah diolah

Dari tabel diatas diperoleh hasil nilai Chi Square sebesar 1,236 dengan nilai signifikansi sebesar 0,996. Nilai signifikansi lebih besar dari tingkat signifikansi sebesar 0,05 atau $0,996>0,05$ yang menunjukkan bahwa model mampu memprediksi nilai observasi. Hal ini berarti model regresi logistik dapat digunakan untuk analisis selanjutnya.

\section{Uji Keseluruhan Model (Overall Model Fit Test)}

Uji ini digunakan untuk menilai model yang telah dihipotesiskan telah fit atau tidak dengan data. Statistik yang digunakan berdasarkan pada fungsi likelihood (Ghozali, 2011:340). Pengujian ini dilakukan dengan membandingkan nilai antara $-2 \quad \log$ likelihood pada awal (block number $=$ 0) dengan nilai -2 log likehood pada akhir (block number =1). Adanya pengurangan nilai antara -2LL awal 
(initial -2LL function) dengan nilai 2LL pada langkah berikutnya (-2LL akhir) menunjukkan bahwa model yang dihipotesiskan fit dengan data. Penurunan nilai -2 log likelihood menunjukkan bahwa model penelitian ini dinyatakan fit, artinya penambahan-penambahan variabel bebas yaitu umur perusahaan, likuiditas dan profitabilitas kedalam model penelitian akan memperbaiki model regresi.

\section{Tabel Hasil Uji Overall Model Fit Test 1}

Iteration History $^{\mathrm{a}, \mathrm{b}, \mathrm{c}}$

\begin{tabular}{|ll|l|l|}
\hline \multicolumn{2}{|l|}{} & & Coefficients \\
\cline { 4 - 4 } Iteration & & -2 Log likelihood & Constant \\
\hline Step 0 & 1 & 88.781 & 1.261 \\
& 2 & 88.059 & 1.470 \\
& 3 & 88.057 & 1.484 \\
& 4 & 88.057 & 1.484 \\
\hline
\end{tabular}

a. Constant is included in the model.

b. Initial -2 Log Likelihood: 88.057

c. Estimation terminated at iteration number 4 because parameter estimates changed by less than .001 .

Sumber : Data sekunder yang telah diolah

Tabel Hasil Overall Model Fit Test 2

\begin{tabular}{|c|c|c|c|c|c|c|}
\hline \multirow{2}{*}{\multicolumn{2}{|c|}{ Iteration }} & \multirow[b]{2}{*}{-2 Log likelihood } & \multicolumn{4}{|c|}{ Coefficients } \\
\hline & & & Constant & AGE & $\mathrm{CR}$ & PROFT \\
\hline \multirow{7}{*}{ Step 1} & 1 & 85.269 & 1.137 & .008 & -.003 & .187 \\
\hline & 2 & 83.789 & 1.267 & .013 & -.004 & .504 \\
\hline & 3 & 82.904 & 1.237 & .012 & -.004 & 1.510 \\
\hline & 4 & 81.628 & 1.122 & .006 & -.001 & 4.898 \\
\hline & 5 & 81.602 & 1.114 & .007 & -.001 & 5.281 \\
\hline & 6 & 81.602 & 1.114 & .007 & -.001 & 5.294 \\
\hline & 7 & 81.602 & 1.114 & .007 & -.001 & 5.295 \\
\hline \multicolumn{7}{|c|}{$\begin{array}{l}\text { a. Method: Enter } \\
\text { b. Constant is included in the model. } \\
\text { c. Initial -2 Log Likelihood: } 88.057\end{array}$} \\
\hline
\end{tabular}

\section{Sumber : Data sekunder yang telah diolah}

Dari hasil tabel diatas menunjukkan adanya perbandingan 2LL awal dengan -2LL akhir. Dimana hasil -2LL awal (Block Number $=0$ ) sebesar 88,057 dan nilai -2LL akhir (Block Number $=1$ ) sebesar 81,062. Sehingga dapat ditunjukkan terjadinya penurunan sebesar 88,057 -81,062= 6,455 . Terlihat dari hasil dapat disimpulkan bahwa model penelitian ini dinyatakan fit, yang artinya penambahan variabel independen seperti umur perusahaan, likuiditas dan profitabilitas mampu memperbaiki model regresi.

\section{Uji Koefisien Determinasi (Model Summary)}

Pengujian koefisien determinasi pada regresi logistik dengan 
menggunakan Nagelkerke's $R$ Square. Tujuan dari pengajuan ini adalah untuk mengetahui seberapa besar kombinasi variabel independen yang terdiri dari umur perusahaan, likuiditas, dan profitabilitas mampu menjelaskan variasi variabel dependen yaitu ketepatan waktu penyampaian laporan keuangan (timeliness).

\section{Tabel Hasil Uji Koefisien Determinasi}

Model Summary
\begin{tabular}{|l|l|l|l|}
\hline Step & -2 Log likelihood & $\begin{array}{l}\text { Cox \& Snell R } \\
\text { Square }\end{array}$ & $\begin{array}{l}\text { Nagelkerke R } \\
\text { Square }\end{array}$ \\
\hline 1 & $81.602^{\mathrm{a}}$ & .068 & .110 \\
\hline
\end{tabular}

a. Estimation terminated at iteration number 7 because parameter estimates changed by less than .001 .

Sumber : Data sekunder yang telah diolah

Dari tabel diatas dapat dilihat bahwa Nagelkerke's $R$ Square sebesar 0,110 atau sebesar $11 \%$. Hal ini berarti bahwa variabel independen dalam penelitian yaitu umur perusahaan, likuiditas dan profitabilitas mampu menjelaskan variasi variabel ketepatan waktu penyampaian laporan keuangan sebesar $11 \%$ sedangkan sebesar $89 \%$ dijelaskan oleh faktor-faktor lain diluar variabel dalam penelitian ini seperti leverage keuangan, ukuran perusahaan, struktur kepemilikan, solvabilitas, reputasi KAP dan opini audit

\section{Uji Simultan (Omnibus Test of Model Coefficient)}

Uji simultan digunakan untuk mengetahui apakah variabel independen seperti umur perusahaan, likuiditas dan profitabilitas secara bersama-sama atau simultan mempengaruhi variabel dependen yaitu ketepatan waktu penyampaian laporan keuangan (timeliness), (Ghozali, 2011: 177).

\section{Tabel Hasil Uji Secara Simultan}

Omnibus Tests of Model Coefficients

\begin{tabular}{|ll|l|l|l|}
\hline & & Chi-square & df & Sig. \\
\hline Step 1 & Step & 6.455 & 3 & .091 \\
& Block & 6.455 & 3 & .091 \\
& Model & 6.455 & 3 & .091 \\
\hline
\end{tabular}

Sumber : Data sekunder yang telah diolah

Berdasarkan tabel diatas dapat dilihat bahwa hasil Chi-Square hitung sebesar 6,455. Untuk tingkat signifikansi sebesar $5 \%$ atau 0,05 dan derajat bebas $=$ 3 diperoleh Chi-Square tabel sebesar 7,815. Nilai Chi-Square hitung lebih kecil dari nilai Chi-Square tabel yaitu 6,455 <
7,815. Sedangkan nilai signifikansi sebesar 0,091 atau lebih besar dari 0,05. Maka dapat disimpulkan bahwa variabel independen seperti umur perusahaan, likuiditas dan profitabilitas secara bersama-sama atau simultan tidak berpengaruh signifikan terhadap 
ketepatan waktu penyampaian laporan keuangan (timeliness).

\section{Uji Koefisien Regresi (uji parsial)}

Pengujian ini dilakukan untuk mengetahui apakah masing-masing variabel independen yang terdiri dari umur perusahaan, likuiditas dan profitabilitas berpengaruh terhadap variabel dependen (timeliness). Pengujian hipotesis dilakukan dengan cara membandingkan antara nilai probabilitas (sign) dengan tingkat signifikansi ( $\alpha$ ) $5 \%$ atau 0,05 .

Tabel Hasil Uji Koefisien Regresi (Parsial) Variables in the Equation

\begin{tabular}{|c|c|c|c|c|c|c|}
\hline & & B & S.E. & Wald & $\mathrm{df}$ & Sig. \\
\hline \multirow[t]{4}{*}{ Step $1^{\mathrm{a}}$} & AGE & .007 & .038 & .030 & 1 & .862 \\
\hline & $\mathrm{CR}$ & -.001 & .014 & .003 & 1 & .953 \\
\hline & PROFT & 5.295 & 3.450 & 2.355 & 1 & .125 \\
\hline & Constant & 1.114 & .689 & 2.612 & 1 & .106 \\
\hline
\end{tabular}

Sumber : Data sekunder yang telah diolah

Berdasarkan tabel diatas, statistik wald untuk variabel umur perusahaan (AGE) sebesar 0,030 sedangkan dari tabel Chi-Square tabel untuk tingkat signifikansi $5 \%$ atau 0,05 dan derajat bebas $=1$ diperoleh hasil 3,841. Nilai probabilitas (sign) sebesar 0,862 dimana hasilnya lebih besar dari signifikansi. Hasil menunjukkan bahwa Wald hitung < Chi-Square tabel yaitu $0,030<3,841$ dan nilai signifikansi $0,862>0,05$. Hal ini memberi makna bahwa hipotesis pertama $\left(\mathrm{H}_{1}\right)$ dalam penelitian ini ditolak. Sehingga dapat disimpulkan bahwa umur perusahaan tidak berpengaruh signifikan terhadap kemungkinan ketepatan waktu penyampaian laporan keuangan.

Statistik Wald untuk variabel likuiditas sebesar 0,003 sedangkan ChiSquare tabel untuk tingkat signifikansi $5 \%$ atau 0,05 dan derajat bebas $=1$ diperoleh hasil 3,841. Nilai probabilitas (sign) sebesar 0,953 dimana hasilnya lebih besar dari signifikansi. Hasil menunjukkan bahwa Wald hitung $0,003<$ 3,841 dan nilai signifikansi $0,953>0,05$.
Hal ini memberi makna bahwa hipotesis kedua $\left(\mathrm{H}_{2}\right)$ dalam penelitian ini ditolak. Sehingga dapat disimpulkan bahwa likuiditas tidak berpengaruh signifikan terhadap kemungkinan ketepatan waktu penyampaian laporan keuangan.

Statistik Wald untuk variabel profitabilitas sebesar 2,355 sedangkan Chi-Square tabel untuk tingkat signifikansi $5 \%$ atau 0,05 dan derajat bebas $=1$ diperoleh hasil 3,841. Nilai probabilitas (sign) sebesar 0,125 dimana hasilnya lebih besar dari signifikansi. Hasil menunjukkan bahwa Wald hitung $2,355<3,841$ dan nilai signifikansi 0,125 $>0,05$. Hal ini memberi makna bahwa hipotesis ketiga $\left(\mathrm{H}_{3}\right)$ dalam penelitian ini ditolak. Sehingga dapat disimpulkan bahwa profitabilitas tidak berpengaruh signifikan terhadap kemungkinan ketepatan waktu penyampaian laporan keuangan.

Untuk melihat hasil analisis regresi logistik digunakan model dengan memasukkkan semua komponen dari seluruh variabel independen. Dari hasil 
tabel 4.11 terlihat bahwa nilai koefisien umur perusahaan (AGE) sebesar 0,007, variabel likuiditas (CR) sebesar -0,001 dan variabel profitabilitas (PROF) sebesar 5,295 . Sehingga persamaan regresi logistik dapat dibentuk sebagai berikut:

$\operatorname{Ln} \frac{\text { TIME }}{1-\text { TIME }}=1,114+0,007$ AGE $-0,001 \mathrm{CR}+5,295$ PROF

Variabel konstan model regresi logistik mempunyai koefisien positif sebesar 1,114. Karena variabel dependen menggunakan data nominal yaitu 0 dan 1, maka nilai konstanta ini mencapai nilai 1 yang berarti kemungkinan ketepatan waktu penyampaian laporan keuangannya memperoleh hasil yang besar.

Koefisien variabel umur perusahaan sebesar 0,007 artinya jika umur perusahaan mengalami kenaikan satu satuan, maka ketepatan waktu penyampaian laporan keuangan mengalami penurunan sebesar 0,007 satuan dengan asumsi variabel independen lainnya tetap.

Koefisien variabel likuiditas sebesar $-0,001$ artinya jika likuiditas mengalami kenaikan satu satuan, maka ketepatan waktu penyampaian laporan keuangan mengalami penurunan sebesar 0,001 satuan dengan asumsi variabel independen lainnya tetap.

Koefisien variabel profitabilitas sebesar 5,295 artinya jika profitabilitas mengalami kenaikan satu satuan, maka ketepatan waktu penyampaian laporan keuangan mengalami penurunan sebesar 5,295 satuan dengan asumsi variabel independen lainnya tetap.

\section{Pembahasan}

Penelitian ini menganalisis umur perusahaan, likuiditas dan profitabilitas terhadap ketepatan waktu penyampaian laporan keuangan (timeliness) ke Bapepam pada perusahaan manufaktur yang terdaftar di BEI untuk periode tahun 2012. Berdasarkan hasil penelitian yang telah dilakukan, penelitian ini membuktikan bahwa variabel independen seperti umur perusahaan, likuiditas dan profitabilitas secara bersama-sama atau simultan tidak berpengaruh signifikan terhadap ketepatan waktu penyampaian laporan keuangan (timeliness). Secara uji parsial juga dapat disimpulkan bahwa semua variabel independen secara parsial tidak berpengaruh signifikan terhadap kemungkinan ketepatan waktu penyampaian laporan keuangan.

\section{Pengaruh Likuiditas terhadap Kemungkinan Ketepatan Waktu Penyampaian Laporan Keuangan (timeliness)}

Hasil pengujian regresi logistik pada variabel likuiditas yang diukur dengan current ratio tidak berhasil membuktikan adanya pengaruh likuiditas terhadap ketepatan waktu penyampaian laporan keuangan (timeliness). Hal ini dapat dilihat bahwa likuiditas mempunyai koefisien sebesar - 0,001 dengan tingkat signifikansi $0,953>0,05$ yang berarti bahwa hipotesis kedua $\left(\mathrm{H}_{2}\right)$ dalam penelitian ini ditolak. Sehingga dapat disimpulkan bahwa likuiditas tidak berpengaruh signifikan terhadap kemungkinan ketepatan waktu penyampaian laporan keuangan. Dimana pada hipotesis yang disusun berpengaruh signifikan terhadap kemungkinan ketepatan waktu penyampaian laporan keuangan. Tetapi pada kenyataan tidak demikian, perusahaan yang memiliki current ratio tinggi maupun rendah tidak dapat menjamin perusahaan akan tepat 
waktu dalam menyampaikan laporan keuangannya.

Fakta ini didukung oleh adanya PT Davomas Abadi Tbk (DAVO) yang memiliki tingkat likuiditas tinggi sebesar 1005,18 . Namun pada kenyataannya perusahaan tidak tepat (terlambat) dalam menyampaikan laporan keuangannya ke Bapepam yaitu pada tanggal 28 Juni 2013.

Penelitian ini tidak mendukung hasil penelitian Suharli dan Rachpriliani (2006) dan Hilmi dan ali (2008) yang menyatakan bahwa likuiditas berpengaruh signifikan positif terhadap ketepatan waktu penyampaian laporan keuangan.

Hasil penelitian ini sejalan dengan penelitian Yusralaini, dkk (2010) yang menyatakan bahwa likuiditas tidak mempunyai pengaruh secara signifikan terhadap ketepatan waktu penyampaian laporan keuangan.

Pengaruh Profitabilitas terhadap Kemungkinan Ketepatan Waktu Penyampaian Laporan Keuangan (timeliness)

Hasil pengujian regresi logistik pada variabel profitabilitas yang diukur dengan ROA tidak berhasil membuktikan adanya pengaruh profitabilitas terhadap ketepatan waktu penyampaian laporan keuangan (timeliness). Hal ini dapat dilihat bahwa profitabilitas mempunyai koefisien sebesar 5,295 dengan tingkat signifikansi $0,125>0,05$ yang berarti bahwa hipotesis ketiga $\left(\mathrm{H}_{3}\right)$ dalam penelitian ini ditolak. Sehingga dapat disimpulkan bahwa profitabilitas tidak berpengaruh signifikan terhadap kemungkinan ketepatan waktu penyampaian laporan keuangan. Dimana pada hipotesis yang disusun berpengaruh signifikan terhadap kemungkinan ketepatan waktu penyampaian laporan keuangan. Tetapi pada kenyataan tidak demikian, perusahaan yang memiliki ROA tinggi maupun rendah tidak dapat menjamin sebuah perusahaan akan tepat waktu dalam menyampaikan laporan keuangannya.

Penelitian ini tidak mendukung hasil penelitian Hilmi dan ali (2008) yang menyatakan bahwa profitabilitas berpengaruh signifikan positif terhadap ketepatan waktu penyampaian laporan keuangan.

Hasil penelitian ini sejalan dengan penelitian Agrianti, KSA (2003) yang menyatakan bahwa ROA mempunyai koefisien negatif yang menunjukkan bahwa semakin rendah ROA semakin tinggi probabilitas perusahaan untuk tidak patuh dalam menyampaikan laporan keuangannya. Pendapat yang menjelaskan kenapa profitabilitas tidak mempengaruhi ketepatan waktu perusahaan untuk penyampaian laporan keuangan ke Bapepam adalah karena manajemen perusahaan tidak menggunakan tingkat profitabilitas sebagai alasan untuk tidak patuh pada peraturan penyampaian laporan keuangan. Karena kinerja manajer perusahaan publik di indonesia tidak dinilai berdasarkan tingkat profitabilitas.

\section{Keterbatasan Penelitian}

Pada penelitian ini memiliki keterbatasan yang dapat mempengaruhi hasilnya, keterbatasan penelitian sebagai berikut ini :

1. Penelitian ini hanya menggunakan tiga variabel independen saja yaitu umur perusahaan, likuiditas dan profitabilitas. Sedangkan masih banyak faktor-faktor yang mempengaruhi ketepatan waktu 
penyampaian laporan keuangan seperti leverage keuangan, ukuran perusahaan, struktur kepemilikan, solvabilitas, reputasi KAP dan opini audit.

2. Sampel penelitian ini hanya perusahaan manufaktur tahun 2012.

3. Data yang dijadikan sampel sangat terbatas yaitu hanya satu tahun periode 2012.

4. Berdasarkan data yang diperoleh dari sumber yang digunakan terdapat banyak perusahaan yang tidak memenuhi kriteria sampel yang telah ditentukan, sehingga memperkecil jumlah sampel yang digunakan dalam penelitian ini.

\section{SIMPULAN, KETERBATASAN DAN KONTRIBUSI PRAKTIS \\ Simpulan}

Sesuai dengan analisis data yang telah dilakukan, maka penelitian menarik beberapa kesimpulan sebagai berikut ini :

1. Dari uji Omnibus Test of Model Coefficient dapat ditunjukkan bahwa variabel independen seperti umur perusahaan, likuiditas dan profitabilitas secara bersama-sama atau simultan tidak berpengaruh signifikan terhadap ketepatan waktu penyampaian laporan keuangan (timeliness).

2. Pada uji parsial untuk semua variabel independen seperti umur perusahaan, likuiditas dan profitabilitas terlihat tidak mempunyai pengaruh yang signifikan terhadap kemungkinan ketepatan waktu penyampaian laporan keuangan (timeliness).

3. Berdasarkan uji koefisien determinasi dapat dilihat bahwa nilai Nagelkerke's $R$ Square sebesar 0,110 atau sebesar $11 \%$. Maka hal ini berarti bahwa variabel independen dalam penelitian yaitu umur perusahaan, likuiditas dan profitabilitas mampu menjelaskan variasi variabel ketepatan waktu penyampaian laporan keuangan sebesar $11 \%$. sedangkan sebesar $89 \%$ dijelaskan oleh faktor-faktor lain diluar variabel dalam penelitian ini seperti leverage keuangan, ukuran perusahaan, struktur kepemilikan, solvabilitas, reputasi KAP dan opini audit.

\section{DAFTAR PUSTAKA} . Undang-Undang Republik Indonesia Nomor 8 Tahun 1995 tentang Pasar Modal. 1995. Jakarta.

Keputusan Ketua Bapepam Dan Lampiran LK Nomor : Kep-346/BL/2011 Tanggal : 5 Juli 2011. Peraturan Nomor X.K.2 : Penyampaian Laporan Keuangan Berkala Emiten Atau Perusahaan Publik. 2011. Jakarta

Agrianti. (2003). Faktor-faktor yang menentukan kepatuhan perusahaan publik terhadap regulasi informasi di Indonesia. Simposium Nasional Akuntansi VI. Surabaya.

Ardiyos. (2010). Kamus besar akuntansi. Jakarta : Citra harta prima.

Aryati dan Theresia. (2005). Faktor-faktor yang mempengaruhi audit delay dan timeliness. Media Riset Akuntansi, Auditing dan Informasi. Volume 5, No.3; 271-278.

Dyer, J.C., \& McHugh, A.L. (1975). The timeliness of the Australian annual report. Journal of Accounting Research. 13(3); 204-219. 
Ghozali, imam. (2011). Aplikasi analisis multivariate dengan program IBM SPSS 19. Semarang : Badan penerbit Universitas Diponegoro.

Harahap, Sofyan Syafri. (2011). Analisis kritis atas laporan keuangan. Jakarta : Rajawali pers.

Hilmi dan Ali. (2008). Analisis faktorfaktor yang mempengaruhi ketepatan waktu penyampaian laporan keuangan. Simposium Nasional Akuntansi XI. Pontianak.

Houston dan Brigham. (2010). Dasardasar manajemen keuangan. Edisi sepuluh. Jakarta : Salemba empat.

Ikatan Akuntan Indonesia. (2012). Standar akuntansi keuangan. Jakarta: IAI

Iyoha, F.O. (2009). State agencies, industry regulations and the quality of accounting practice in Nigeria. Unpublished PhD dissertation, Covenant University.

Kasmir. (2011). Analisis laporan keuangan. Jakarta : Rajawali pers.

Na'im, Ainun. (1999). Nilai informasi ketepatan waktu penyampaian laporan keuangan : Analisis empirik regulasi di Indonesia. Jurnal Ekonomi dan Bisnis Indonesia. Volume 14, No.2; 85100.

Owusu dan Ansah. (2000). Timeliness of corporate financial reporting in emerging capital markets : Empirical evidence from the Zimbabwe Stock Exchange. Accounting \& Business Research. Volume 30, No. 3, Summer 2000

Rachmawati, Sistya. (2008). Pengaruh faktor internal dan eksternal perusahaan terhadap audit delay dan timeliness. Jurnal Akuntansi \& Keuangan. Volume 10, No.1; 1-10.
Render dan Heizer. (2005). Manajemen operasi. Edisi tujuh. Buku 1. (Dwianoegrahwati Setyoningsih dan Indra Almahdy, Penerjemah) Jakarta : Salemba Empat.

Saleh, Rachmat. (2004). Studi empiris ketepatan waktu pelaporan keuangan perusahaan manufaktur di Bursa Efek Jakarta. Simposium Nasional Akuntansi VII. Denpasar.

Sitanggang, J.P. (2012). Manajemen keuangan perusahaan. Jakarta: Mitra Wacana Media

Subramanyam \& John J. Wild. (2010). Analisis laporan keuangan.. Edisi sepuluh buku kedua. Jakarta : Salemba empat.

Suharli dan Rachpriliani. (2006). Studi empiris faktor berpengaruh terhadap ketepatan waktu pelaporan keuangan. Jurnal Bisnis dan Akuntansi. Volume 8, No. 1; 34-55.

Suwardjono. (2010). Teori akuntansi. Edisi ketiga. Yogyakarta : BPFE Universitas Gadjah Mada.

Yusralaini, Restu dan Raesya. (2010). Analisis faktor-faktor yang mempengaruhi ketepatan waktu penyampaian laporan keuangan ke publik pada perusahaan yang terdaftar di BEI. Jurnal Ekonomi, Volume 18, Nomor 2 Juni 2010.

http://wartaekonomi.co.id/berita13538/pe njualan-meningkat-8-namun-lababersih-sipd-turun-35.html diakses 25 Oktober 2013 (19:46 WIB) 